Relations industrielles

Industrial Relations

\title{
Psychological Contract and Quality of Organizational Life
} An Empirical Study on Workers at a Rest Home Contrat psychologique et qualité de la vie organisationnelle Une recherche empirique sur les employés d'une maison de retraite

\section{Contrato sicológico y calidad de la vida organizacional Un estudio empírico sobre los trabajadores de una casa de reposo}

\author{
Martina Battisti, Franco Fraccaroli, Rino Fasol et Marco Depolo
}

Volume 62, numéro 4, automne 2007

Construction de nouveaux rapports à l'organisation du travail dans les transitions professionnelles Constructing New Relationships with the Work Organization in Occupational Transitions

URI : https://id.erudit.org/iderudit/016956ar DOI : https://doi.org/10.7202/016956ar

\section{Aller au sommaire du numéro}

\section{Éditeur(s)}

Département des relations industrielles de l'Université Laval

\section{ISSN}

0034-379X (imprimé)

1703-8138 (numérique)

Découvrir la revue

Citer cet article

Battisti, M., Fraccaroli, F., Fasol, R. \& Depolo, M. (2007). Psychological Contract and Quality of Organizational Life: An Empirical Study on Workers at a Rest Home. Relations industrielles / Industrial Relations, 62(4), 664-689. https://doi.org/10.7202/016956ar

\section{Résumé de l'article}

La notion de contrat psychologique joue à l'heure actuelle un rôle de plus en plus important dans le domaine de la psychologie du travail et des organisations. Le contrat psychologique se rapporte aux croyances sur les obligations réciproques existant entre l'employé et l'organisation : ces croyances reposent sur la perception que des promesses ont été faites par l'employeur (salaires compétitifs, avancement de carrière, formation professionnelle) en échange d'autres promesses faites par l'employé (loyauté, honnêteté, engagement) (Rousseau, 1989; Rousseau et Tijoriwala, 1998).

Dans cette recherche, le contrat psychologique a été analysé en utilisant la méthode de mesure axée sur les caractéristiques créée par Sels, Janssens et Van den Brande (2004). Celle-ci analyse le contrat psychologique sur la base de six éléments, à savoir la durée, la tangibilité, le but, la stabilité, le niveau du contrat et la symétrie de l'échange. Cette échelle révèle les perceptions de l'employé sur deux aspects : par rapport aux obligations que l'employeur a envers lui, et par rapport aux obligations qu'il estime avoir lui-même envers l'employeur. La perception du travailleur de son propre contrat psychologique est donc analysée à travers deux grilles de questions. Cependant, les perceptions de l'employeur n'ont pas été prises en compte. Dans la présente étude, l'hypothèse était que les caractéristiques du contrat psychologique ont des conséquences spécifiques dans le rapport de travail. En particulier, on s'attendait à ce que les obligations perçues de l'employeur soient en rapport avec les attitudes et les perceptions de l'employé en ce qui perçues de l'employeur soient en rapport avec les attitudes et les perceptions de l'employé en ce qui
concerne son rôle professionnel (à savoir, les attentes d'avancement et l'ambiguïté de rôle). Nous avons formulé l'hypothèse que les obligations perçues de l'employé étaient liées à la composante affective et formulé l'hypothèse que les obligations perçues de l'employé étaient liées à la composante affective et
motivationnelle du rapport de travail et, notamment, aux perceptions de justice organisationnelle et à motivationnelle du rappor l'engagement affectif.

Cette étude se base sur une recherche menée dans une maison de retraite de l'Italie du Nord. Un questionnaire a été soumis à 170 individus employés dans cette structure avec des tâches différentes (principalement des travailleurs dans le domaine de l'assistance sociale et des infirmiers) : 147 femmes et 23 hommes ; 33,3 \% âgés de moins de 36 ans ; 34,5\% d'âge compris entre 36 et 45 ans ; $32,2 \%$ âgés de plus de 45 ans. Le questionnaire a été autorempli. Le traitement statistique des données a été effectué à l'aide des programmes SPSS (pour les statistiques descriptives et les analyses de la variance) et AMOS (pour vérifier les modèles expérimentaux supposés).

En ce qui concerne le rapport entre le contrat psychologique et les résultats organisationnels, les hypothèses énoncées ont été confirmées : la perception des obligations de l'employeur a un lien positif avec les attentes d'avancement et négatif avec l'ambiguïté de rôle, tandis que les obligations perçues de l'employé sont liées à la justice organisationnelle et à l'engagement de type affectif. La tangibilité constitue une exception : dans ce cas, les obligations de l'employé n'ont aucun lien ni avec la justice, ni avec l'engagement affectif, mais, au contraire, elles sont liées aux attentes d'avancement. Il paraît donc que la tangibilité est liée aux perspectives de progrès de l'employé à l'intérieur de son propre rôle professionnel, indépendamment du fait que l'on mesure la perception des obligations de l'employeur ou de l'employé.

Ces résultats nous montrent que plus l'employé perçoit que l'employeur a des obligations fortes envers lui, plus il aura le sentiment de maîtriser sa tâche professionnelle (en termes de faible ambigüité de rôle); en outre, il considérera l'organisation comme un lieu dans lequel il peut avancer et développer ses compétence et sa carrière professionnelle (en termes d'attentes d'avancement). Par contre, plus le travailleur perçoit qu'il a pris des obligations fortes envers l'organisation, plus il considérera celle-ci comme un lieu où s'engager; par conséquent, il développera des sentiments d'attachement affectif et il considérera comme plus équitables et justes les modalités par lesquelles l'organisation prend ses décisions et les communique. Cette recherche montre encore une fois l'importance du contrat psychologique dans la formation de la qualité du rapport de travail. Elle montre également que la perception des obligations de l'employeur et de
l'employé contribuent de façon significative à la création d'un rapport de travail satisfaisant et gratifiant pour les deux parties. Il devient donc fondamental pour les gestionnaires d'avoir pleine conscience de l'importance de cette notion et des conséquences positives pouvant découler d'une correcte interprétation et du respect des conditions qui la composent.
Tous droits réservés (C Département des relations industrielles de l'Université Laval, 2007
Ce document est protégé par la loi sur le droit d'auteur. L'utilisation des services d'Érudit (y compris la reproduction) est assujettie à sa politique d'utilisation que vous pouvez consulter en ligne.

https://apropos.erudit.org/fr/usagers/politique-dutilisation/ 


\title{
Psychological Contract and Quality of Organizational Life \\ An Empirical Study on Workers at a Rest Home
}

\author{
Martina Battisti \\ Franco Fraccaroli \\ RINO FASOL \\ Marco Depolo
}

This study assesses psychological contract using a featureoriented approach which measures perceptions about employer and employee obligations along the dimensions of duration, tangibility, scope, stability/flexibility, contract level and exchange symmetry. Questionnaires were administered to 170 workers $(23$ males, 147 females) employed at a rest home in Northern Italy. The results confirm the hypothesized relation between the employee's perceptions of employer obligations and the organizational role component of organizational life (in terms of low role ambiguity and high development expectations). Similarly, the hypothesized relation between the employee's perceived obligations to the employer and the affective and motivational area is supported (in terms of affective commitment and perceived organizational justice). The results also show the importance of assessing the employee's perceptions both of employer obligations and of her/his own obligations to the employer, considering the differentiated influence that each of them has on organizational life.

- Battisti, M., Department of Sociology and Social Research, University of Trento, Italy, martina.battisti@soc.unitn.it

- Fraccaroli, F., Department of Cognitive Sciences and Education, University of Trento, Italy, franco.fraccaroli@unitn.it

- Fasol, R., Department of Sociology and Social Research, University of Trento, Italy, rino.fasol@unitn.it

- Depolo, M., Department of Education Sciences, University of Bologna, Italy, marco. depolo@unibo.it 
The world of work has undergone major transformations in the past decade, principally because of economic recessions, the increasing pervasiveness of new technologies, corporate restructurings, increased global competition, and the flexibilization of work contracts (Anderson and Schalk, 1998; Conway and Briner, 2005; Ho, 2005; Toderi and Guglielmi, 2003). Centered on flexibility and cost cutting, these changes have had major impacts on the relationship between organization and worker, and they have profoundly altered the content of the relationship between the employer and the employee (De Vos, Buyens and Schalk, 2005; Sarchielli, 2003). In this context, the psychological contract is playing a key role in shedding light on the contemporary employment relationship (Sels, Janssens and Van den Brande, 2004; Sturges et al., 2005). According to the most recent definitions, the psychological contract consists in individual beliefs concerning what has been promised to the worker by the organization (competitive pay, opportunities for career advancement, job security) and what the employee has promised the organization in exchange (loyalty, honesty, good quality performance) (Deery, Iverson and Walsh, 2006; Lester et al., 2002; Rousseau, 1989). In recent years, many studies have demonstrated that the psychological contract is an important determinant of the behaviours and attitudes of workers: compliance with, or breach of, the terms of the psychological contract have profound consequences for the employment relationship. Widely documented is the connection between the psychological contract and positive organizational outcomes like affective commitment (Janssens, Sels and Van den Brande, 2003; Lester et al., 2002; Sels, Janssens and Van den Brande, 2004), organizational citizenship behaviour (Hui, Lee and Rousseau, 2004), employee performance (Tekleab and Taylor, 2003), job satisfaction (Kickul, Lester and Finkl, 2002; Lambert, Edwards and Cable, 2003). But also widely analyzed are the negative consequences that may ensue from breach of the contract, like the intention to leave the company (Sturges et al., 2005; Tekleab and Taylor, 2003), absenteeism (Deery, Iverson and Walsh, 2006) or increased cynicism regarding organizational life. Nevertheless, while consequences of breach of (or compliance with) the terms of psychological contracts have been widely studied, little attention has been paid to the influence of psychological contract features on the quality of organizational life (Sels, Janssens and Van den Brande, 2004; Shore and Barksdale, 1998).

The purpose of this study is to analyse the psychological contract and some of its outcomes using a feature-oriented approach (Janssens, Sels and Van den Brande, 2003; Sels, Janssens and Van den Brande, 2004). The aim is to examine how the features of the psychological contract may influence two different components of the quality of organizational life.

The employee's attitudes and perceptions toward her/his organizational role. Many studies have documented the influence of the psychological 
contract on the employee's perceptions and attitudes to her/his organizational role. Sels and colleagues (2004) detected a positive relationship of psychological contract features with perceived level of control on organizational role: the higher the level of psychological contract features, the higher the employee's perception of being in control of her/his role. Shore and Barksdale (1998) discovered that relationships based on highlevel reciprocal obligations exhibited much higher levels of future career expectations and lower levels of turnover intentions. In this study two other variables are introduced in regard to the employee's interpretation of her/his organizational role: development expectations (Battistelli and Odoardi, 2004) and role ambiguity (Almudever et al., 2000; Rizzo, House and Lirtzman, 1970). More specifically, the aim is to analyse the relationship of psychological contract features with these two constructs.

The affective and motivational component of organizational life. Many studies have examined the influence of the psychological contract on the affective and motivational area of organizational life. Shore and Barksdale (1998) demonstrated that employees with psychological contracts comprising high-level obligations have much higher levels of perceived organizational support and affective commitment. Many studies have documented a positive relationship between the psychological contract and organizational citizenship behaviour (Turnley et al., 2003), perceived organizational justice (Kickul, Lester and Finkl, 2002), and trust toward the employer (Deery, Iverson and Walsh, 2006). However, these studies have mainly focused on the consequences of breach (or fulfilment) of the psychological contract. The purpose of this study is to examine whether these components of organizational life are influenced also by psychological contract features. More specifically, the aim is to analyse the influence of psychological contract features on affective commitment and perceived organizational justice.

These general aims are more precisely specified in the next sections: first the theoretical framework is introduced; then the adopted featureoriented approach is described; finally the hypotheses at the basis of this study are formulated.

\section{THEORETICAL FRAMEWORK}

\section{What is Psychological Contract?}

According to the most recent definitions (Deery, Iverson and Walsh, 2006; Lester et al., 2002), psychological contracts have two key features.

The psychological contract is reciprocal. It contains individual beliefs regarding the mutual obligations of both parties to the relationship. This 
aspect derives directly from the theory of social exchange (Blau, 1964) whereby one individual who supplies services to another creates an obligation for the latter, who, in order to remove this obligation must in exchange return benefits to the former (Deery, Iverson and Walsh, 2006; Shore and Barksdale, 1998). In the case of the psychological contract, the offer by the employer of a secure and well-paid job creates the obligation on the employee to be committed to her/his work and faithful and loyal to the organization. This imposes the further obligation on the employer to ensure that the worker's good employment conditions continue.

The psychological contract consists in individual beliefs. It is an intrinsically subjective phenomenon, partly because of human cognitive and perceptive limitations, but also because there are many sources of information that may influence the development and modification of the contract (Shore and Tetrick, 1994). It is shaped by multi-level factors that affect the meaning of the promises and commitments exchanged by worker and employer. The beliefs embodied in the psychological contract derive from factors preceding the employment relationship (values, beliefs acquired from primary socialization), from on-the-job experiences (the practices of organizational socialization, the promises made during job interviews, communication with superiors), and from the broader societal context (Dabos and Rousseau, 2004; De Vos, Buyens and Schalk, 2005; Dick, 2006). This implies that each party to the employment relationship (the employer and the employee) may have different perceptions of what reciprocal obligations are, so that in order to effectively assess psychological contracts, it is necessary to consider both the employer's and the employee's perspective (Guest, 1998). Nevertheless, Rousseau (1998) states that this incurs the risk of anthropomorphizing the organization because, especially in big and medium-sized companies, it is not easy to identify who constitutes the employer: the recruiter, or the supervisor, or top management. Therefore the most widespread formulation of the concept puts it firmly in the mind of the employee alone. Some studies have assessed both employee and employer perceptions of the psychological contract (Dabos and Rousseau, 2004; Herriot, Manning and Kidd, 1997; Lester et al., 2002). However, although they make it possible to restore mutuality to the psychological contract, to date they have represented only a small part of the existing literature, and much work has still to be done in identifying effective and shared ways to assess the perceptions of both the parties to the employment relationship.

This study focuses on the employee's perceptions about the employer's obligations toward her/him and about her/his own obligations toward the employer. It therefore does not consider the employer's perspective. 


\section{How the Psychological Contract is Measured?}

Although the psychological contract is of increasing importance in studies on organizational psychology, there is little agreement among researchers on how it should be measured. The numerous approaches taken to measurement of the construct have given rise to a large number of assessment methods, creating an "embarrassing richness" (Sels, Janssens and Van den Brande, 2004: 461). Awareness of the profound heterogeneity of current research has prompted Rousseau and Tijoriwala (1998) to propose a classification to guide future research. They distinguish three types of measurement:

- Content-oriented: which examines the specific terms and obligations characterizing the psychological contract (Coyle-Shapiro and Conway, 2005; Coyle-Shapiro and Kessler, 2002; Dabos and Rousseau, 2004; Dick, 2006; Rousseau, 2000). The best-known examples of content-oriented assessments are those based on the distinction between transactional psychological contracts (shortterm work agreements focused mainly on economic exchange) and relational contracts (long-term agreements involving mutually satisfactory relations with open-ended commitments comprising both economic and socio-emotional aspects) (Ho, Rousseau and Levesque, 2006; Rousseau, 2000; Thomas, Au and Ravlin, 2003);

- Evaluation-oriented: this approach concentrates on subjective experience in terms of the organization's maintenance of its promises (fulfillment), breach of the psychological contract (violation), or change to its contents (change) (Lambert, Edwards and Cable, 2003: Lester et al., 2002; Morrison and Robinson, 1997; Robinson and Morrison, 2000). The approach is mainly used when the researcher wants to analyze the organizational outcomes of the psychological contract (for example, affective commitment and job satisfaction in the case of fulfillment; high turnover or distrust in the case of breach or violation);

- Feature-oriented: this method assesses various properties differentiating among psychological contracts, such as the extent to which they are implicit or explicit, static or dynamic, certain or uncertain, written or unwritten; these properties are conceptually independent of the specific contents of the psychological contract.

The present study adopts this last approach, which is based on the research by Sels, Janssens and Van den Brande (2004). Drawing on the theoretical structure of studies on the psychological contract by MacNeil (1985) and by Rousseau and McLean Parks (1993), on industrial relations studies, and on a cross-national study of the psychological contract 
conducted in 2000 and coordinated by Rousseau and Schalk, Sels and colleagues (2004) identified six features with which to capture the nature of the psychological contract:

1. Duration (short-term vs. long-term) is the extent to which the employment relationship is perceived as of long or short duration. Indicators of a long-term relationship are job security, promotion based on seniority, and little external mobility; conversely, a limited number of open-ended contracts and high mobility are indicative of a short-term psychological contract.

2. Tangibility (tangible vs. intangible) indicates the extent to which the employee perceives the terms of the contract as unambiguously defined, explicitly specified, and clearly observable by a third party. An employment relationship is tangible if there are numerous written agreements, if job descriptions are specific, and if performance requirements and evaluation criteria are explicit. Indicators of intangible relationships are a broad definition of roles and a large reliance on trust.

3. Scope (narrow vs. broad) is the extent to which the boundaries between a person's employment relationship and other aspects of her/his life are perceived as permeable. A psychological contract has narrow scope if there is a strict division between work and personal life, or if the employee shows low job involvement. By contrast, the scope is broad if the employer is interested in the employee's family situation, or if the employee is willing to make sacrifices for the good of the company.

4. Stability (stable vs. flexible) indicates the extent to which the psychological contract is limited in terms of its ability to evolve and change without this implying renegotiation of its terms. Indicators of a stable psychological contract are a strict application of rules, little flexibility in organizational practices, and a low tolerance of uncertainty. Conversely, flexible employment relationships exhibit high tolerance of uncertainty and change, and continuous reinterpretation of roles.

5. Exchange symmetry (equal vs. unequal) is the extent to which the employee perceives an unequal and hierarchical employment relationship as acceptable. Acceptance of hierarchy and inequality is expressed mainly as respecting orders and obeying hierarchical authority.

6. Contract level (individual vs. collective) is the extent to which employees perceive aspects of their employment relationship as collectively or individually regulated. In collective contracts, 
all aspects of employment have been collectively decided. All employees are treated in the same way, and trade unions have a prominent role. In individual contracts, by contrast, individual negotiations and agreements are possible.

The scale constructed by Sels and colleagues (2004) is addressed to employees in particular. It therefore measures how the psychological contract is perceived by only one of the parties. Unlike most studies on psychological contracts, this one, besides assessing the employee's perceptions of the employer's obligations, also measures the obligations which the employee perceives her/himself as holding toward the employer. This is consistent with a conception of the psychological contract as a social exchange relationship in which it is important to consider the perceived obligations of both parties to the employment relationship (Shore and Barksdale, 1998). Therefore two questionnaires are administered to the employee. The purpose of the first is to assess the employee's perception of the organization's obligations to her/him; the purpose of the second is to assess employee's believed obligations to the organization.

\section{RATIONALE AND HYPOTHESES}

The aim of this study is to analyze how various aspects of organizational life may be influenced by features of the contract: according to the level of the perceived obligations of both the employer and the employee, specific organizational outcomes may be expected to ensue. The adoption of a featureoriented approach and dual assessment of the employee's perception of both her/his own obligations and those of the employer allow the formulation of more specific hypotheses on the relationship between the psychological contract and the elements of organizational life examined. Although the employee's perception of her/his own obligations and of the employer's may be significantly related, this study hypothesizes that each of these dual perceptions exerts a differentiated influence on the two components of organizational life considered (organizational role component, and the affective and motivational area). More precisely, this study hypothesizes that the employee's perception of the employer's obligations exerts a significant influence on aspects of the former's organizational role (in terms of higher development expectations and lower perceived role ambiguity). In parallel, the study hypothesizes that the employee's perceived obligations to the employer are significantly linked with affective and motivational features (in terms of affective commitment and perceived organizational justice).

\section{Aspects of the Organizational Role}

The influence of the psychological contract on the employee's attitudes and perceptions concerning her/his organizational role is widely documented 
(Sels, Janssens and Van den Brande, 2004; Shore and Barksdale, 1998). This study tests the relationship between the psychological contract and two components of the employee's organizational role (development expectations and role ambiguity). These have not been studied as outcomes of the psychological contract, yet: nevertheless, they are important elements in employees' perceptions of their organizational role, and understanding how they may be affected by features of the psychological contract may be a significant contribution to the literature. More specifically, we assumed that these two constructs are influenced by the employee's perceptions of the employer's obligations. The hypothesis is that the employee's perception of the employer's obligations exerts a significant influence on the employee's interpretation of her/his own organizational role. This is hypothesized for all the features examined. No relationship is expected to be found between the employee's perception of the employer's obligations and the affective area of organizational life.

Development expectations (Battistelli and Odoardi, 2004) refer to the importance given by workers to self-fulfillment and the achievement of certain goals in their careers within the organization. This variable indicates commitment to the organizational role. If workers can expect a great deal from their employer (in terms of long-term, tangible, broad scope, stable and collectively regulated perceived obligations), it is likely that they will conceive their future at work and their personal development as tied to the organization: they will therefore perceive their jobs as worth investing in and as opportunities for personal growth.

H1. The employee's perceived obligations of the employer correlate positively with the employee's expectations of development within the organization.

Role ambiguity occurs when information about appropriate role behaviour in the organization is inadequate or confusing. The worker finds it difficult to understand the specific objectives and tasks of her/his job in relation to those of colleagues and superiors; the division of labour in her/ his department or office is unclear; and the attribution of responsibility for results is uncertain (Almudever et al., 2000; Rizzo, House and Lirtzman, 1970). When employees can expect a great deal from their employer, it is likely that they will feel more in control of their work and have greater clarity and confidence concerning their roles and their performance (Sels, Janssens and Van den Brande, 2004). Hypothesized as a consequence is a negative relation with role ambiguity.

H2. The employee's perceived obligations of the employer correlate negatively with role ambiguity. 


\section{Affective and Motivational Aspects}

The relationship between the psychological contract and affective and motivational components of organizational life has been widely documented (Deery, Iverson and Walsh, 2006; Hui, Lee and Rousseau, 2004; Janssens, Sels and Van den Brande, 2003; Robinson and Morrison, 2000; Turnley et al., 2003). In the purpose of this study is to examine the relationship of psychological contract features with two variables characterizing this area of the employment relationship: more specifically, the employee's perceived obligations to the employer are hypothesized as being related to perceptions of organizational justice and affective commitment. If employees perceive themselves to be highly committed to their employer (in terms of employment relationships consisting of long-term, tangible, broad scope, flexible and with unequal exchange symmetry obligations), they are likely to develop more positive feelings and attitudes toward the organization. They will feel more involved in the organization and more willing to invest in it (Shore and Barksdale, 1998) in order to maintain reciprocity in their social exchange relationship with the employer (Blau, 1964). No relationship is expected between the employee's perception of her/his obligations to the employer and the organizational role area.

Organizational justice concerns the perceptions of justice/injustice of an organization's workers and the individual and organizational consequences of those perceptions. The relationship between the degree of fulfillment of the psychological contract and perceptions of justice has been demonstrated by several studies (Kickul, Lester and Finkl, 2002; Robinson and Morrison, 2000). Here it is hypothesized that the more engaged the employee is toward the employment relationship, the greater her/his perception of organizational justice.

H3. The employee's perceived obligations to the employer are positively correlated with perceptions of organizational justice.

Affective commitment (Meyer and Allen, 1997) is the worker's sense of belonging and attachment to the organization. The worker is dedicated to her/his work and through this commitment seeks to protect the organizational interests because $s /$ he endorses its goals. Affective commitment reflects the employee's attachment to the organization to which s/he belongs, identification with it, and involvement in its activities. The perception of being committed to the organization is likely to be accompanied by greater affective attachment to it, because the relationship is perceived as something in which to invest.

H4. The employee's perceived obligations to the employer correlate positively with affective commitment. 
In order to verify these four hypotheses (from $\mathrm{H} 1$ to H4), we tested the model reported in Figure 1 for each feature of the psychological contract.

FIGURE 1

\section{Model Tested for Each Dimension of the Psychologica Contract (PC)}

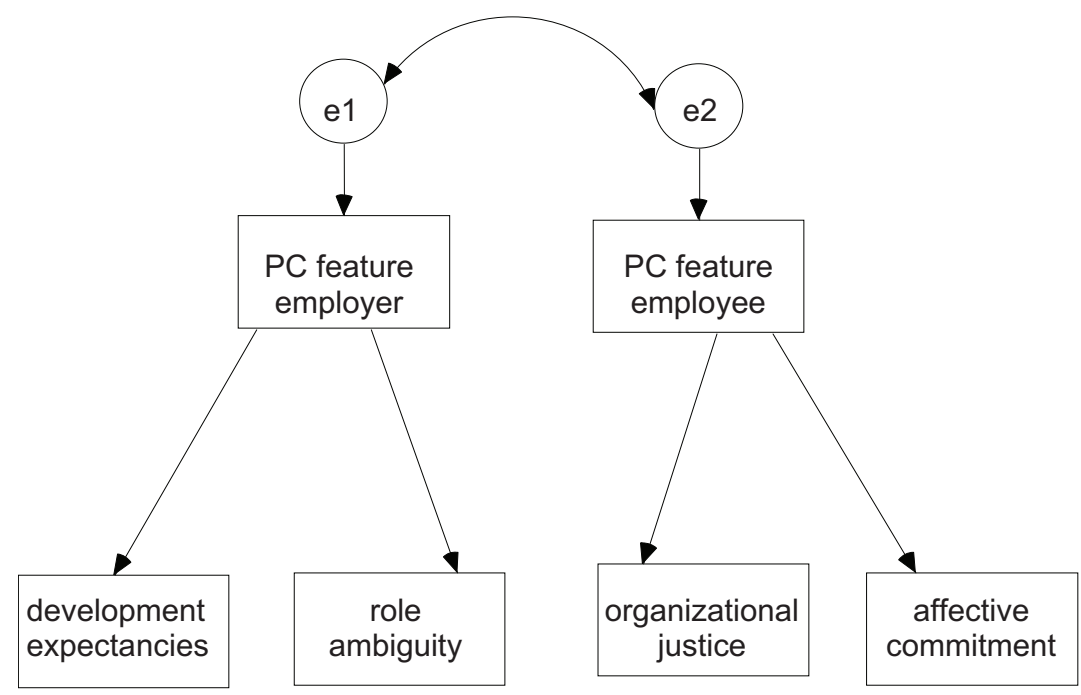

To sum up: for each of the features of the psychological contract we hypothesized that the employee's perceived obligations of the employer are positively associated with development expectations and negatively with role ambiguity, while the employee's perceived obligations to the employer are positively correlated with perceptions of organizational justice and affective commitment.

\section{METHOD}

\section{Participants and Procedure}

Questionnaires were administered to 170 employees (23 males; 147 females) of a rest home for the elderly in North Italy. The ages of the subjects were distributed as follows: $33.3 \%$ aged under $36 ; 34.5 \%$ aged between 36 and $45 ; 32.2 \%$ aged over $45.21 .5 \%$ of the subjects had worked at the facility for 1 year or less; $29.5 \%$ from 2 to 5 years; $20.2 \%$ from 6 to 10 years; $28.8 \%$ for 11 years and more. The respondents were employed in various jobs furnishing care and assistance to the elderly residents. The questionnaire was administered to groups of workers, who 
completed it during working hours under the supervision of a member of the research team. This study was part of a wider action-research project on reorganization at the rest home investigated: therefore all the workers were involved in it.

\section{Measures}

For each variable (apart from development expectations), the respondents were asked to indicate their agreement with each statement on a Likert scale from 1 to $5(1=$ entirely disagree, $5=$ completely agree $)$. The scales used were translated from English into Italian using the translationback translation procedure.

\section{Psychological Contract}

Employer's obligations: Sixteen items adapted from Sels, Janssens and Van den Brande's (2004) scale. Our scale measures the perception of the employer's obligations along five features:

- duration (example item: "I expect my employer to offer me a secure job");

- tangibility ("I expect my employer to specifically describe the appraisal criteria used in this firm");

- scope ("I expect my employer to appreciate me for what I do and who I am");

— stability ("I expect my employer to stick to agreements despite changed circumstances");

- contract level ("I expect my employer to treat all employees at the same level equally").

As regards exchange symmetry, Sels and colleagues (2004) propose items that are unsuitable for factor analysis. Consequently, this feature is not assessed in the questionnaire measuring the employer's obligations.

Employee's obligations: Fifteen items adapted from the Sels and colleagues' scale (2004). The scale measures the employee's perceived obligations to the employer; these obligations are assessed along the following five features:

- duration (example item: "My employer can expect me to commit myself to this firm for a long time");

- tangibility ("My employer can expect me to indicate clearly if problems arise"):

- scope ("My employer can expect me to bring my ideas and creativity into the firm"); 
- flexibility ("My employer can expect me to adjust easily to changes in my work situation");

- exchange symmetry (unequal) ("My employer can expect me to adopt a formal attitude to my superiors").

As regards contract level, Sels and colleagues (2004) do not propose items suitable for factor analysis. Consequently, this feature is not assessed in the questionnaire measuring the employee's obligations.

Development expectations: Fifteen items adapted from Battistelli and Odoardi (2004). Example items: "During my career in the organization it is important that I am appreciated for the knowledge I have gained from training and experience"; "During my career in the organization it is important that I progress in my career". Respondents have to indicate their response on a 5 -point Likert scale $(1=$ not at all important for me, $5=$ extremely important for me).

Role ambiguity: Two items taken from Rizzo, House and Lirtzman (1970). Example item: "In my job I know exactly what is expected of me" (reverse scored).

Perception of justice: Eight items adapted from Niehoff and Moorman (1993). Example items: "My supervisor takes decisions about work impartially" and "My supervisor discusses the implications of decisions about my job with me".

Affective commitment: Four items adapted from Meyer and Allen (1997). Example item: "I would be very happy to spend the rest of my career with this organization".

\section{Data Analysis}

The main descriptive statistics for each variable (mean, standard deviation, and coefficients of correlation among variables) were calculated. The internal consistency of each variable was evaluated by means of Cronbach's alpha. Internal consistency was not calculated for Stability (employer), Exchange symmetry (employee) and Role ambiguity, because these scales are made up of only two items. Analysis of Variance (ANOVA) was used to determine whether there were differences by sex, age and organizational tenure in regard to all the variables considered.

The goodness of the models presented in Figures 2 and 3 was then evaluated through analysis of structural equations using the AMOS program (Arbuckle and Wothke, 1999). The indicators of the model's goodness of fit considered were: (a) Chi-square with degrees of freedom; (b) Goodness of the Fit Index (GFI), which indicates the relative quantity of variance and covariance explained by the model; (c) Adjusted Goodness of the Fit Index 
(AGFI), which recalculates the GFI in function of the model's degrees of freedom; (d) Root Mean Square Residual (RMR), which indicates the average discrepancy between the observed and hypothesized covariance matrices; (e) Comparative Fit Index, (CFI) with a value ranging from 0 to 1 , where 1 indicates perfect fit; (f) Root Mean Square Error of Approximation (RMSEA), in which values less than .06 (Hu and Bentler, 1999) or .08 (Arbuckle and Wothke, 1999; Browne and Cudeck, 1992) indicate an acceptable fit.

\section{RESULTS}

\section{Descriptive Statistics}

Means, standard deviations, internal consistency coefficients, and correlation values among the variables are set out in Table 1 , which shows that employer obligations are generally perceived as much lower than employee ones, especially in duration (mean for employer obligations $=3.87$; mean for employee obligations $=3.25$ ) and scope (employer obligations $=4.36$; employee obligations $=3.17$ ). By contrast, the gap regarding tangibility is quite small (employer obligations $=3.84$; employee obligations $=3.75$ ). In general, considering that responses range from 1 to 5 , it is possible to conclude that the situation of organizational life is generally perceived as positive. There is a quite high level of development expectations among the respondents $($ mean $=3.67)$ and of affective commitment $($ mean $=3.22)$; perceived organizational justice is of medium level (mean $=3.01)$; and role ambiguity has a quite low level (mean $=2.75)$. The analysis of variance indicates that there are no significant differences either for gender or for age or for organizational tenure.

\section{Testing the Goodness of the Models}

We tested the models described above for each feature of the psychological contract. Considering the close relation between affective commitment and perceptions of organizational justice $(\mathrm{r}=.43, p<.01$, see Table 1), we decided to estimate the correlation between the errors of these two variables in the models. This close relation is not surprising: both affective commitment and perceived organizational justice are part of the employees' motivational involvement in their organization, so it is reasonable to expect these variables to be strongly linked. The models tested for each psychological contract feature are depicted in Figures 2 and 3. Figure 2 shows the models tested for the features of Duration, Tangibility, Scope and Stability (employer)/Flexibility (employee). Figure 3 displays the models tested for the features of Contract level (employer) and Exchange 


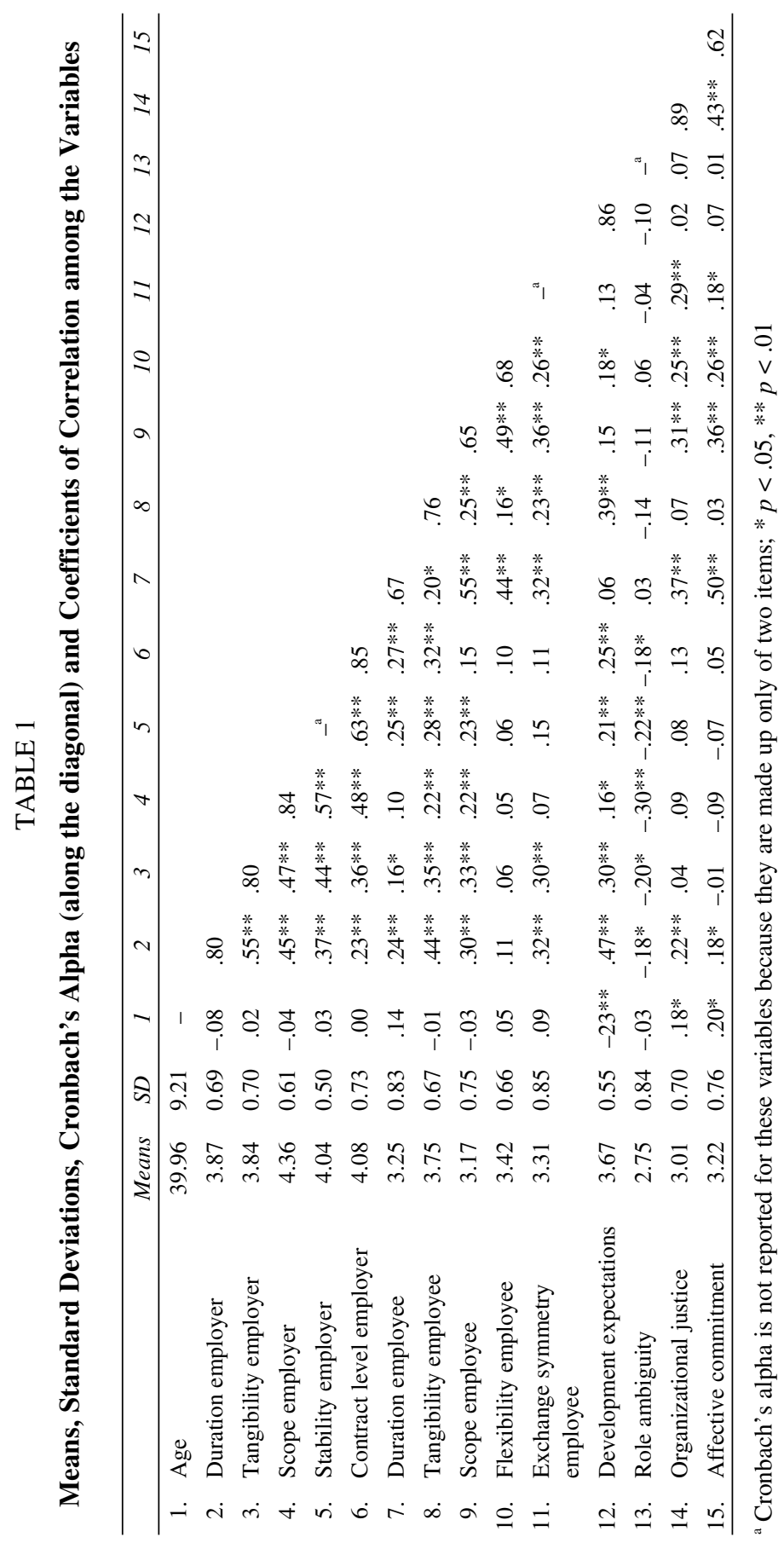


symmetry (employee). Analysis of structural equations was used to test the goodness of each model.

FIGURE 2

\section{Models tested for Duration, Tangibility, Scope, Stability (Employer)/ Flexibility (Employee)}

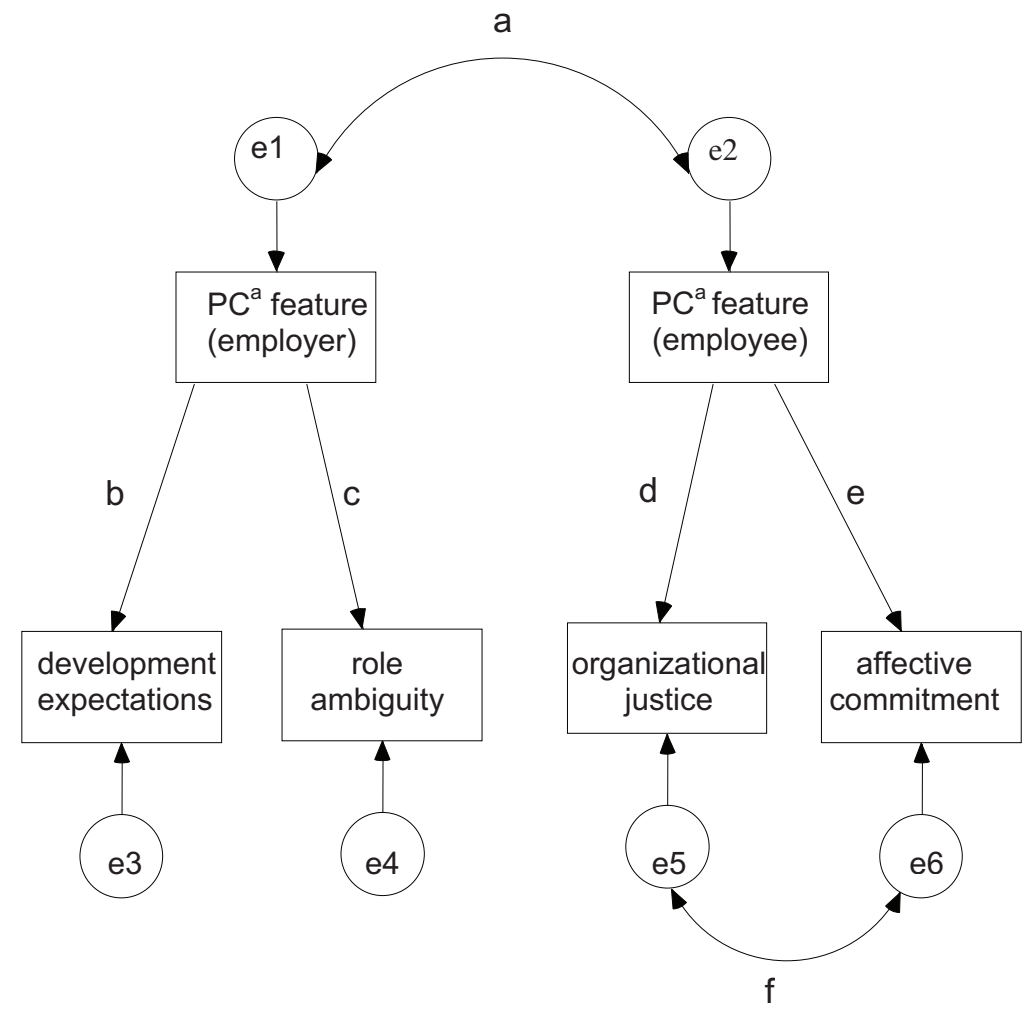

\begin{tabular}{ccccc}
\hline & Model 1 & Model 2 & Model 3 & Model 4 \\
\hline Path coefficients & Duration & Tangibility & Scope & $\begin{array}{c}\text { Stability (employer)/ } \\
\text { Flexibility (employee) }\end{array}$ \\
\hline a & $.23 * *$ & $.34 * * *$ & $.21 * *$ & .06 \\
b & $.45^{* * *}$ & $.29 * * *$ & $.14 *$ & $.20 * *$ \\
c & $-.18^{*}$ & $-.23 * *$ & $-.25 * * *$ & $-.20^{* *}$ \\
$\mathrm{~d}$ & $.36 * * *$ & .07 & $.30^{* * *}$ & $.24 * * *$ \\
$\mathrm{e}$ & $.49 * * *$ & .03 & $.34 * * *$ & $.26 * * *$ \\
$\mathrm{f}$ & $.28^{* * *}$ & $.40^{* * *}$ & $.34 * * *$ & $.37 * * *$ \\
\hline
\end{tabular}

${ }^{\mathrm{a}} \mathrm{PC}=$ Psychological Contract; $* p<.05, * * p<.01, * * * p<.001$ 
Duration. The indices of fit are: $\chi^{2}(9)=11.05\left(\chi^{2} / \mathrm{df}=1.23, p=\right.$ non significant); $\mathrm{GFI}=.98 ; \mathrm{AGFI}=.95 ; \mathrm{CFI}=.98 ; \mathrm{RMR}=.03 ; \mathrm{RMSEA}=.04$. All of them have satisfactory values (greater than 0.90 for GFI, AGFI, CFI; below .05 for RMR; below .08 for RMSEA) (Arbuckle and Wothke, 1999; Browne and Cudeck, 1992). All the path coefficients, moreover, are significant $(p<.05)$.

Tangibility. The model tested for Tangibility does not entirely satisfactorily fit with the data: $\chi^{2}(9)=21.92\left(\chi^{2} / \mathrm{df}=2.44, p<.01\right)$; $\mathrm{GFI}=.96 ; \mathrm{AGFI}=.91 ; \mathrm{CFI}=.84 ; \mathrm{RMR}=.03 ; \mathrm{RMSEA}=.09$. Tangibility in regard to the employer's obligations confirms the hypothesis because it exhibits a significant relation with development expectations $(\beta=.29$, $p<.001)$ and role ambiguity $(\beta=-.23, p<.01)$. By contrast, the employee's obligations do not exhibit any relation with perceptions of justice and with affective commitment. The modification indices suggest that estimation should also be made of the relation between the employee's obligations as regards tangibility and development expectations. In this case the model significantly improves in goodness: $\chi^{2}(8)=6.00\left(\chi^{2} / g l=0.75\right)$; $\mathrm{GFI}=.99 ; \mathrm{AGFI}=.97 ; \mathrm{CFI}=.99 ; \mathrm{RMR}=.02 ; \mathrm{RMSEA}=.01$. It therefore seems that the feature of tangibility, as regards the obligations of both the employer and employee, has more to do with the worker's attitudes to her/his organizational role than with the motivational and affective features considered.

Scope. Model 3 (Figure 2) has satisfactory indices of fit: $\chi^{2}(9)=15.92$ $\left(\chi^{2} / \mathrm{df}=1.77, p=\right.$ non significant $) ; \mathrm{GFI}=.97 ;$ AGFI $=.93 ; \mathrm{CFI}=.91 ;$ $\mathrm{RMR}=.03 ; \mathrm{RMSEA}=.07$. Moreover, all the path coefficients are significant with $p<.05$.

Employer stability/employee flexibility. Also Model 4 has satisfactory indices of fit: $\chi^{2}(9)=16.65\left(\chi^{2} / \mathrm{df}=1.85, p=\right.$ non significant $)$; GFI $=.97$; $\mathrm{AGFI}=.93 ; \mathrm{CFI}=.88 ; \mathrm{RMR}=.03 ; \mathrm{RMSEA}=.07$. All the path coefficients are significant with $p<-.05$.

Contract level. The model tested in this case (Model 5, see Figure 3) comprises only the employer's obligations, because Sels and colleagues (2004) did not propose satisfactory items with which to measure the employee's obligations. In this case, the purpose of the model is to examine the relation between the employer's perceived obligations and all the outcome variables. The indices of fit are: $\chi^{2}(5)=7.02\left(\chi^{2} / \mathrm{df}=1.40, p=\right.$ non significant); $\mathrm{GFI}=.98 ; \mathrm{AGFI}=.95 ; \mathrm{CFI}=.96 ; \mathrm{RMR}=.03 ; \mathrm{RMSEA}=.05$. One notes from the path coefficients that the contract level is significantly associated only with development expectations $(\beta=.24, p<.01)$ and with role ambiguity $(\beta=-.17, p<.05)$, while the relation with the other two outcome variables is not significant. 
FIGURE 3

Models Tested for Contract Level (Employer) and Exchange Symmetry-Unequal (Employee)

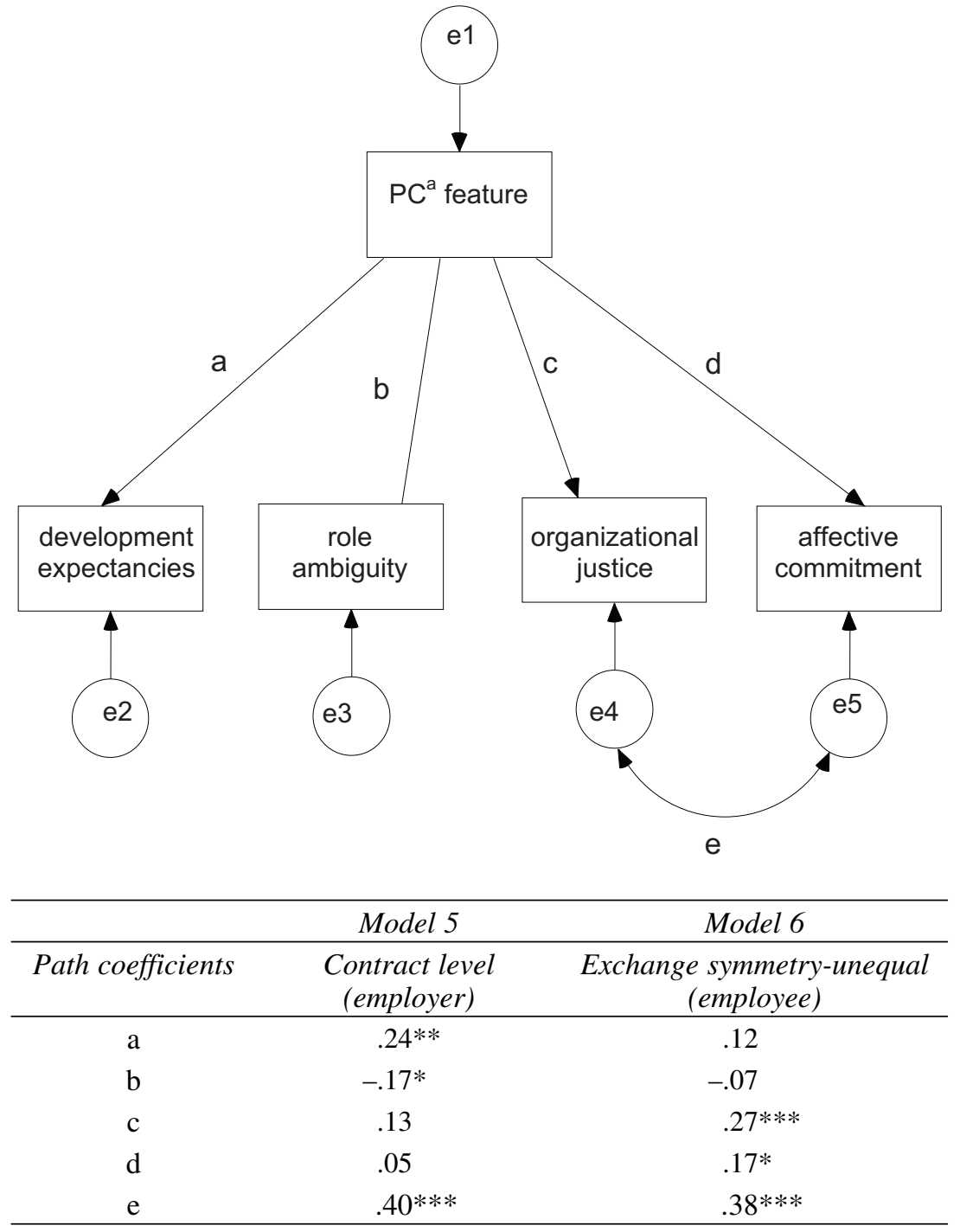

${ }^{\mathrm{a}} \mathrm{PC}=$ Psychological Contract; $* p<.05, * * p<.01, * * * p<.001$

Exchange symmetry. Model 6 concerns the feature of exchange symmetry. This is measured only as regards the employer's obligations because Sels and colleagues (2004) did not propose satisfactory items with 
which to measure this feature in respect to employer's obligations. As in the previous case, all four outcome variables are examined in the model in order to reveal any relations between exchange symmetry and development expectations and role ambiguity. The goodness of the model is satisfactory: $\chi^{2}(5)=8.19\left(\chi^{2} / \mathrm{df}=1.64, p=\right.$ non significant $) ; \mathrm{GFI}=.98 ; \mathrm{AGFI}=.94 ;$ $\mathrm{CFI}=.93 ; \mathrm{RMR}=.03 ; \mathrm{RMSEA}=.06$. In this case too, as hypothesized, this feature of the employee's obligations is significantly associated with justice $(\beta=.27, p<.001)$ and affective commitment $(\beta=.17, p<.05)$, but not with development expectations and role ambiguity.

As hypothesized, all the features of the psychological contract exert significant influence on the various aspects of organizational life. All the features of the psychological contract regarding the employer's obligations display a significant relation with variables to do with the employee's attitudes to her or his organizational role (development expectations and role ambiguity). Hypotheses 1 and 2 are therefore confirmed. Vice versa, perceived employer's obligations are not related to the motivational and affective component of organizational life. The employee's obligations exhibit a significant relation with justice and organizational commitment, thereby confirming Hypotheses 3 and 4. By contrast, employee's obligations are not significantly related to the organizational role area. The only exception is tangibility. As regards the employee's obligations, this feature is associated with development expectations, but not with the other three outcome variables. This is probably due to the fact that tangibility, which indicates the extent to which the terms of the psychological contract are explicit and specified, has more to do with the employee's expectations of work development within the organization.

\section{DISCUSSION AND CONCLUSIONS}

Although the notion of psychological contract is increasingly widespread in the organizational and managerial literature, many of its aspects are still controversial, and far from being agreed upon by scholars. This study has used a relatively recent and innovative scale to evaluate the psychological contract (Janssens, Sels and Van den Brande, 2003; Sels, Janssens and Van den Brande, 2004). Unlike the approaches most widely used, which evaluate the psychological contract using content-oriented measurements (Herriot, Manning and Kidd, 1997; Rousseau, 2000) or evaluation-oriented ones (Conway and Briner, 2002, 2005; Robinson and Morrison, 2000), the approach taken here has focused on the features of the psychological contract. Although this kind of measurement is still little used (Shore and Barksdale, 1998), it has potential of great interest. The measurement adopted here has the merit of evaluating the psychological contract with features which, although new, have a sound theoretical basis 
(they have not been invented ex novo but are derived from the studies by MacNeil (1985), Rousseau and McLean Parks (1993) and Rousseau and Schalk (2000)). Moreover, the distinctive feature of this scale is that, whilst most studies in the literature evaluate only the employee's perception of the employer's obligations (Conway and Briner, 2002), it measures the employee's perception of both the employer's obligations towards her/him and her/his obligations to the employer, consistently with a conception of the psychological contract as a social exchange relationship (Blau, 1964; Shore and Barksdale, 1998).

The results show that employees' perceptions of their employer's obligations to them are significantly correlated with their attitudes to organizational role (in terms of high development expectations and low role ambiguity). The extent to which an employee feels obligated to the employer instead exerts an influence mainly on certain motivational and affective features (organizational justice and affective commitment). This suggests that the employee's perceptions of the employer's obligations and of her/his own obligation to the employer exert differentiated influences on organizational life. On one hand, the level of perceived employer obligations has mainly to do with the amount of resources which the employee is willing to invest in her/his role and with her/his feeling of being in control of it. If the employee perceives that the employer has assumed high-level obligations toward her/him, s/he will probably feel more attached to her/his role: this can be attributed to the fact that this perceived high commitment by the employer will induce the employee to increase her/his feeling of being in possession of her/his role. Therefore, psychological contracts including long-term commitment by the employer, high tangibility and specification, high stability, in which the employee is considered not only as a worker but also as a person, and in which the terms are collectively regulated, will induce the employee to feel that s/he is in control of her/his role and that it is worth investing in it. It is interesting to note that, on the contrary, employer obligations have nothing to do with the affective and motivational component. On the other hand, the obligations which the employee perceives to have assumed vis-à-vis the employer have a significant relationship with her/his attachment and attitudes to the organization. If these last obligations are perceived as high, the employee will probably feel more engaged to the organization in fulfilling her/his own part of the psychological contract and maintaining balance in her/his employment relationship (Shore and Barksdale, 1998). Therefore, if s/he perceives her/himself as having assumed a long-term and tangible commitment to the employer; as having undertaken to be flexible and to accept an unequal exchange relationship; and as contributing to the organization not just as a worker but also as a person (in terms of creativity, interest in organizational activities), s/he is likely to develop both attachment to the organization (in 
terms of high affective commitment) and more positive attitudes to it (in terms of perceived organizational justice). An interesting result is that the employee's perceived obligations to the employer are not linked to role ambiguity, nor to development expectations (except for tangibility).

An abundance of studies shows the importance of the psychological contract for various aspects of the worker's life within the organization. It has been repeatedly demonstrated, in fact, that workers react to a perception that the contract has been violated by reducing their commitment to the organization (Sturges et al., 2005), their organizational citizenship behaviours (Turnley et al., 2003), their trust in the employer, and their job satisfaction (Coyle-Shapiro and Kessler, 2002; Lambert, Edwards and Cable, 2003); and by increasing their cynicism towards the organization and their intentions of leaving the firm (Lester et al., 2002; Sturges et al., 2005). Conversely, it has been found that respect for the terms of the contract has positive effects for both the individual and the organization: a heightened feeling of being valued, increased perception of organizational justice (Robinson and Morrison, 2000), trust in the employer (Deery, Iverson and Walsh, 2006; Lambert, Edwards and Cable, 2003) and civic virtue within the organization (Coyle-Shapiro and Conway, 2005; Hui, Lee and Rousseau, 2004). The findings of this study reflect those of others. Yet, whilst it confirms and replicates results already obtained elsewhere, it has a number of interesting novel features: rather than focusing on the outcomes of breach or fulfillment of the psychological contract, in fact, it has concentrated on the organizational consequences deriving from the features of the contract. Hence it follows that it is not only important that the obligations comprised in the contract are fulfilled by the parties; it is also essential to consider the level and the quality of those obligations and promises (Lambert, Edwards and Cable, 2003). In other words, besides focusing on fulfillment rather than violation of the contract, one should bear in mind the importance of the features of the promises exchanged by the employer and the worker. Level of fulfillment remaining equal, an agreement based on high-level obligations (for example, with long duration, high tangibility, and broad scope) is more likely to generate consequences satisfactory to both parties than an exchange based on low-level obligations (with short duration, low tangibility, and narrow scope).

\section{Shortcomings}

Our study has the following limitations. First, the research was crosssectional (all the data were collected at the same time), which means that it is not possible to draw conclusions about cause and effect among items based on employee responses. Future longitudinal research is therefore needed to confirm the conclusions drawn by this study. Second, our data 
were collected in only one organization, and this imposes limits as far as generalizability is concerned. Studies conducted in several organizational settings, involving workers with different jobs and in different productive sectors, would enable verification of the generalizability of the results. Third, the organization examined operates in the public sector, where employees benefit from particularly solid work contracts in terms of duration and career prospects. It would be advisable to broaden the research context to include organizations characterized by greater job instability, consistent with contemporary trends in the world of work. In recent years, new pacts based on greater flexibility, instability, and autonomy have arisen (Anderson and Schalk, 1998; Ho, 2005), and it may be that this research context was not the appropriate one in which to grasp the nature of changing psychological contracts and their consequences on organizational life. Finally, by definition, the psychological contract arises between the two parties to the employment relationship: the employee and the employer. But this study has evaluated only the employee's perceptions of the obligations comprised in the psychological contract; future research, therefore, should examine these matters from the employer's point of view (Coyle-Shapiro and Conway, 2005; Coyle-Shapiro and Kessler, 2002).

\section{Implications for Managerial Practices}

This study has confirmed the importance of the psychological contract for the quality of organizational life in many respects. It has shown that the perception of the employer's obligations tends to shape attitudes to the organizational role. In parallel, the study has also pointed out the importance of the employee's assumed obligations to the organization in regulating the perception of justice, motivational involvement, and the affective bond with it. This study therefore heightens understanding of the psychological contract and further highlights its importance for managerial practices. The results confirm that, if workers are to be motivated to grow, and if they are to be affectively tied to the organization and to their organizational roles, the employer must endeavour to establish psychological contracts comprising high-level obligations for both parties. Understanding the dynamics whereby the psychological contract arises and is maintained in the worker's mind is of central importance for management. If the organization fails to understand and adequately fulfill the obligations of the psychological contract, negative consequences - such as perceptions of injustice or role ambiguity-may ensue for the employment relationship.

The results appear to show that positive and balanced relations in terms of perceived reciprocal commitment between employees and employer give rise to greater investment in the organizational position, more value set on the work role, and more intense affective commitment. Benefits 
accrue to both parties: to the organization, which can rely on personnel fully committed to investing personally in the success of the company; to the workers, who are probably more satisfied with their work, feel more appreciated, and have a sense of organizational belonging.

\section{REFERENCES}

Almudever, B., M. Depolo, F. Fraccaroli and V. HajJar. 2000. "Conflitto e ambiguità di ruolo: validità di costrutto di una scala nella versione francese e italiana." Bollettino di Psicologia Applicata, 230 (1), 57-66.

Anderson, N. and R. Schalk. 1998. "The Psychological Contract in Retrospect and Prospect." Journal of Organizational Behavior, 19 (Special Issue), 637-647.

Arbuckle, J. L. and W. Wothke. 1999. AMOS 4.0 User's Guide. Chicago: SPSS.

ARGYRIS, C. 1962. Understanding Organizational Behavior. Homewood: Dorsey Press.

Battistelli, A. and C. OdoARDi. 2004. "Les composantes individuelles et organisationnelles de la motivation à la formation des adultes salariés." Compétences, Carrières, Evolutions au Travail. A. Lancry and C. Lemoine, eds. Paris: L'Harmattan, 185-196.

Blau, P. M. 1964. Exchange and Power in Social Life. New York: Wiley.

BRowne, M. W. and R. CuDECK. 1992. "Alternative Ways of Assessing Model Fit." Sociological Methods and Research, 21 (2), 230-258.

Conway, N. and R. B. Briner. 2002. "A Daily Diary Study of Affective Responses to Psychological Contract Breach and Exceeded Promises." Journal of Organizational Behavior, 23 (3), 287-302.

CONWAY, N. and R. B. BRINER. 2005. Understanding Psychological Contracts at Work: A Critical Evaluation of Theory and Research. Oxford: Oxford University Press.

Coyle-Shapiro, J. A. M. and N. Conway. 2005. "Exchange Relationships: Examining Psychological Contracts and Perceived Organizational Support." Journal of Applied Psychology, 90 (4), 774-781.

Coyle-Shapiro, J. A. M. and I. Kessler. 2002. "Exploring Reciprocity through the Lens of the Psychological Contract: Employee and Employer Perspectives." European Journal of Work and Organizational Psychology, 11 (1), 69-86.

Dabos, G. E. and D. M. Rousseau. 2004. "Mutuality and Reciprocity in the Psychological Contracts of Employees and Employers." Journal of Applied Psychology, 89 (1), 52-72.

De Vos, A., D. Buyens and R. Schalk. 2005. "Making Sense of a New Employment Relationship: Psychological Contract-Related Information Seeking and the Role of Work Values and Locus of Control." International Journal of Selection and Assessment, 13 (1), 41-52. 
DeERy, S. J., R. D. IVerson and J. T. WAlsh. 2006. "Toward a Better Understanding of Psychological Contract Breach: A Study of Customer Service Employees." Journal of Applied Psychology, 91 (1), 166-175.

Dick, P. 2006. "The Psychological Contract and the Transition from Full- to Part-Time Police Work." Journal of Organizational Behavior, 27 (1), 37-58.

Guest, D. 1998. "Is the Psychological Contract Worth Taking Seriously?" Journal of Organizational Behavior, 19 (Special Issue), 649-664.

Herriot, P., W. E. G. Manning and J. M. KidD. 1997. "The Content of the Psychological Contract.” British Journal of Management, 8 (2), 151-162.

Ho, V. T. 2005. "Social Influence on Evaluations of Psychological Contract Fulfilment." Academy of Management Review, 30 (1), 113-128.

Ho, V. T., D. M. Rousseau and L. Levesque. 2006. "Social Networks and the Psychological Contract: Structures Holes, Cohesive Ties, and Beliefs Regarding Employer Obligations." Human Relations, 59 (4), 459-481.

Hu, L. and P. M. BENTLER. 1999. "Cutoff Criteria for Fit Indices in Covariance Structure Analysis: Conventional Criteria versus New Alternatives." Structural Equation Modeling, 6 (1), 1-55.

Hui, C., C. LeE and D. M. Rousseau. 2004. "Psychological Contract and Organizational Citizenship Behavior in CHINA: Investigating Generalizability and Instrumentality." Journal of Applied Psychology, 89 (2), 311-321.

Janssens, M., L. Sels and I. Van Den Brande. 2003. "Multiple Types of Psychological Contracts: A Six-Cluster Solution.” Human Relations, 56 (11), 1349-1378.

KiCKUL, J., S. W. LeSTER and J. FinKL. 2002. "Promise Breaking During Radical Organizational Change: Do Justice Interventions Make a Difference?" Journal of Organizational Behavior, 23 (Special Issue), 469-488.

LAMBERT, L. S., J. EdwARdS and D. M. CABLE. 2003. "Breach and Fulfilment of the Psychological Contract: A Comparison of Traditional and Expanded Views." Personnel Psychology, 56 (4), 895-934.

Lester, S. W., W. H. Turnley, J. M. Bloodgood and M. C. Bolino. 2002. "Not Seeing Eye to Eye: Differences in Supervisor and Subordinate Perceptions of and Attributions for Psychological Contract Breach." Journal of Organizational Behavior, 23 (1), 39-56.

Levinson, H. 1962. Organizational Diagnosis. Cambridge: Harvard University Press.

MACNeIL, I. R. 1985. "Relational Contract: What We Do and Do Not Know." Wisconsin Law Review, 483-525.

Meyer, J. and N. Allen. 1997. Commitment in the Workplace: Theory, Research and Application. Thousand Oaks: Sage.

Morrison, E. W. and S. L. Robinson. 1997. "When Employees Feel Betrayed: A Model of How Psychological Contract Violation Develops." Academy of Management Review, 22 (1), 226-256. 
Niehoff, B. P. and R. H. Moorman. 1993. "Justice As a Mediator of the Relationship Between Methods of Monitoring and Organizational Citizenship Behaviour." Academy of Management Journal, 36 (3), 527-556.

Rizzo, J. R., R. J. House and S. I. LiRTzman. 1970. "Role Conflict and Ambiguity in Complex Organizations." Administrative Science Quarterly, 15 (2), 150-163.

Robinson, S. L. and E. W. Morrison. 2000. "The Development of Psychological Contract Breach and Violation: A Longitudinal Study." Journal of Organizational Behavior, 21 (5), 525-546.

RoussEAU, D. M. 1989. "Psychological and Implied Contracts in Organizations." Employee Rights and Responsibilities Journal, 2 (2), 121-139.

Rousseau, D. M. 1998. "The 'Problem' of the Psychological Contract Considered." Journal of Organizational Behavior, 19 (Special Issue), 665-671.

Rousseau, D. M. 2000. Psychological Contract Inventory: Technical Report (Tech. Rep. No. 2). Pittsburgh: Carnegie Mellon University.

Rousseau, D. M. and J. McLean Parks. 1993. "The Contracts of Individuals and Organizations." Research in Organizational Behavior. L. L. Cummings and B. M. Straw, eds. Greenwich: JAI Press, vol. 15, 1-47.

Rousseau, D. M. and S. A. Tijoriwala. 1998. "Assessing Psychological Contracts: Issues, Alternatives and Measures." Journal of Organizational Behavior, 19 (Special Issue), 679-695.

Rousseau, D. M. and R. Schal, eds. 2000. Psychological Contracts in Employment: Cross-National Perspectives. Thousand Oaks: Sage.

SARChIElli, G. 2003. Psicologia del Lavoro. Bologna: Il Mulino.

Sels, L., M. JANSSEnS and I. VAn DEn Brande. 2004. "Assessing the Nature of Psychological Contracts: A valIdation of Six Dimensions." Journal of Organizational Behavior, 25 (4), 461-488.

SHORE, L. M. and K. BARKSDALE. 1998. "Examining Degree of Balance and Level of Obligation in the Employment Relationship: A Social Exchange Approach." Journal of Organizational Behavior, 19 (Special Issue), 731-744.

Shore, L. M. and L. E. Tetrick. 1994. "The Psychological Contract as an Explanatory Framework in the Employment Relationship." Trends in Organizational Behavior. C. L. Cooper and D. M. Rousseau, eds. Chichester: Wiley, vol. 1, 91-109.

Sturges, J., N. Conway, D. Guest and A. Liefooghe. 2005. "Managing the Career Deal: The Psychological Contract as a Framework for Understanding Career Management, Organizational Commitment and Work Behavior." Journal of Organizational Behavior, 26 (7), 821-838.

Tekleab, A. G. and M. S. Taylor. 2003. "Aren't There Two Parties in an Employment Relationship? Antecedents and Consequences of OrganizationEmployee Agreement on Contract Obligations and Violations." Journal of Organizational Behavior, 24 (Special Issue), 585-608. 
Thomas, D. C., K. Au and E. C. Ravlin. 2003. "Cultural Variation and the Psychological Contract." Journal of Organizational Behavior, 24 (5), 451-471.

Toderi, S. and D. Guglielmi. 2003. "Contratto psicologico: uno strumento per la prevenzione del disagio nelle organizzazioni." Mobbing: quando la prevenzione è intervento. M. Depolo, ed. Milano: Angeli, 87-106.

Turnley, W. H., M. C. Bolino, S. W. Lester and J. M. Bloodgood. 2003. "The Impact of Psychological Contract Fulfilment on the Performance of InRole and Organizational Citizenship Behaviours." Journal of Management, 29 (2), 187-206.

\section{RÉSUMÉ}

\section{Contrat psychologique et qualité de la vie organisationnelle: une recherche empirique sur les employés d'une maison de retraite}

La notion de contrat psychologique joue à l'heure actuelle un rôle de plus en plus important dans le domaine de la psychologie du travail et des organisations. Le contrat psychologique se rapporte aux croyances sur les obligations réciproques existant entre l'employé et l'organisation : ces croyances reposent sur la perception que des promesses ont été faites par l'employeur (salaires compétitifs, avancement de carrière, formation professionnelle) en échange d'autres promesses faites par l'employé (loyauté, honnêteté, engagement) (Rousseau, 1989; Rousseau et Tijoriwala, 1998).

Dans cette recherche, le contrat psychologique a été analysé en utilisant la méthode de mesure axée sur les caractéristiques créée par Sels, Janssens et Van den Brande (2004). Celle-ci analyse le contrat psychologique sur la base de six éléments, à savoir la durée, la tangibilité, le but, la stabilité, le niveau du contrat et la symétrie de l'échange. Cette échelle révèle les perceptions de l'employé sur deux aspects : par rapport aux obligations que l'employeur a envers lui, et par rapport aux obligations qu'il estime avoir lui-même envers l'employeur. La perception du travailleur de son propre contrat psychologique est donc analysée à travers deux grilles de questions. Cependant, les perceptions de l'employeur n'ont pas été prises en compte.

Dans la présente étude, l'hypothèse était que les caractéristiques du contrat psychologique ont des conséquences spécifiques dans le rapport de travail. En particulier, on s'attendait à ce que les obligations perçues de l'employeur soient en rapport avec les attitudes et les perceptions de l'employé en ce qui concerne son rôle professionnel (à savoir, les attentes d'avancement et l'ambiguité de rôle). Nous avons formulé l'hypothèse que les obligations perçues de l'employé étaient liées à la composante affective 
et motivationnelle du rapport de travail et, notamment, aux perceptions de justice organisationnelle et à l'engagement affectif.

Cette étude se base sur une recherche menée dans une maison de retraite de l'Italie du Nord. Un questionnaire a été soumis à 170 individus employés dans cette structure avec des tâches différentes (principalement des travailleurs dans le domaine de l'assistance sociale et des infirmiers) : 147 femmes et 23 hommes; 33,3\% âgés de moins de 36 ans ; 34,5\% d'âge compris entre 36 et 45 ans; $32,2 \%$ âgés de plus de 45 ans. Le questionnaire a été autorempli. Le traitement statistique des données a été effectué à l'aide des programmes SPSS (pour les statistiques descriptives et les analyses de la variance) et AMOS (pour vérifier les modèles expérimentaux supposés).

En ce qui concerne le rapport entre le contrat psychologique et les résultats organisationnels, les hypothèses énoncées ont été confirmées : la perception des obligations de l'employeur a un lien positif avec les attentes d'avancement et négatif avec l'ambiguïté de rôle, tandis que les obligations perçues de l'employé sont liées à la justice organisationnelle et à l'engagement de type affectif. La tangibilité constitue une exception : dans ce cas, les obligations de l'employé n'ont aucun lien ni avec la justice, ni avec l'engagement affectif, mais, au contraire, elles sont liées aux attentes d'avancement. Il paraît donc que la tangibilité est liée aux perspectives de progrès de l'employé à l'intérieur de son propre rôle professionnel, indépendamment du fait que l'on mesure la perception des obligations de l'employeur ou de l'employé.

Ces résultats nous montrent que plus l'employé perçoit que l'employeur a des obligations fortes envers lui, plus il aura le sentiment de maitriser sa tâche professionnelle (en termes de faible ambiguïté de rôle); en outre, il considérera l'organisation comme un lieu dans lequel il peut avancer et développer ses compétence et sa carrière professionnelle (en termes d'attentes d'avancement). Par contre, plus le travailleur perçoit qu'il a pris des obligations fortes envers l'organisation, plus il considérera celle-ci comme un lieu où s'engager; par conséquent, il développera des sentiments d'attachement affectif et il considérera comme plus équitables et justes les modalités par lesquelles l'organisation prend ses décisions et les communique.

Cette recherche montre encore une fois l'importance du contrat psychologique dans la formation de la qualité du rapport de travail. Elle montre également que la perception des obligations de l'employeur et de l'employé contribuent de façon significative à la création d'un rapport de travail satisfaisant et gratifiant pour les deux parties. Il devient donc fondamental pour les gestionnaires d'avoir pleine conscience de l'importance de cette notion et des conséquences positives pouvant découler d'une correcte interprétation et du respect des conditions qui la composent. 